\title{
Moral counselling: a method in development
}

\author{
Jack de Groot MA, MSc, BCC \\ Hospital Chaplain \\ Radboud University Medical Centre Nijmegen, The Netherlands \\ Carlo Leget PhD \\ Associate Professor \\ Tilburg University, The Netherlands
}

Correspondence may be sent to: Jack de Groot UMC St Radboud, 20 DGVP, P.O. Box 91016500 HB Nijmegen, The Netherlands, tel. + 31243613320 email: j.degroot@dgvp.umcn.nl; Carlo Leget email: c.j.w.leget@uvt.nl

\begin{abstract}
This article describes a method of moral counselling developed in the Radboud University Medical Centre Nijmegen (the Netherlands). The authors apply insights of Paul Ricoeur to the non-directive counselling method of Carl Rogers in their work of coaching patients with moral problems in health care. The developed method was shared with other health care professionals in a training course. Experiences in the course and further practice led to further improvement of the method.
\end{abstract}

Keywords: moral counselling; non-directive counselling; Ricoeur; Rogers, shared decision making

Introduction, aim and overview

Whis article describes the a method of moral counselling developed in the Radboud University Medical Centre Nijmegen, the Netherlands. Although moral counselling is done by many health care professionals in every day care, it seems to be an implicit practice to which hardly any attention is paid in the literature. There are no articles mentioned in Medline with 'moral counselling' in the title. During our research we found only one publication (Cattorini 2001) which referred to that term. Nevertheless the topic is important, because all important decisions in human life have a moral dimension. This is also the case in the dialogue between physician and patient, i.e. shared decision making. Many times a patient has difficulties with decision making not because of the information provided, but because of the moral confusion that is generated by the information. In such cases the patient is in need of a counsellor who can serve as coach in the decision making process in order to provide value clarification directed toward a wise decision. Nelson, Han, Fagerlin, Stefanek, and Ubel (2007) argue that clarifying values and preferences is neither a simple nor a clear-cut task. Additionally, an optimal decision is dependent on both values clarification as well as intuitive factors. The aim of moral counselling with a patient is to improve satisfaction and reduce moral distress regarding the decisions made, so that the patient may have 'peace of mind' in the future.

In this article we introduce moral counselling as it is done by a hospital chaplain. In the Dutch situation to which we refer a hospital chaplain is called 'spiritual counsellor' (see http://www.vgvz.nl/userfiles/files/Professional\%20Standard\%20Spiritual\%20Counsellors\%20 2005.pdf). The spiritual counsellor supports the patient in such a way that he or she can make a wise decision in case the physician poses a dilemma in the medical situation. Our aim is to describe the Nijmegen method of moral counselling with regards to both the development of its theoretical background and its impact on the quality of care in the hospital. The Nijmegen method of moral counselling combines the ideas of such philosophers (ethicists) as Ricoeur (1992; 2000), Nussbaum (1990; 2001) and Brennan (1977) with the experience and theories of counselling experts and therapists like Rogers (1942; 1966) and Egan (1997). The method facilitates argumentative, cognitive and rational aspects of patients' decision-making processes as well as intuitive, emotive and narrative elements. It allows for the way in which people make moral decisions (Greene and Haidt 2002; Haidt 2001). The method is particularly suited for decisions to be made in tragic situations.

Our description starts with Ricoeur's moral complementarity model (van der Ven 1998), which incorporates teleological and deontological considerations and combines them with the 
importance of wisdom in the actual situation While applying Ricoeur's ideas in counselling as described by Rogers we also sharpen our focus with the help of Nussbaum and Brennan who ask attention for non-rational 'arguments'. We describe the development of the method in collaboration with colleagues in different courses and trainings on the method and we end with some considerations on the role of the hospital chaplain in relation to the method.

Ricoeur's moral complementarity

The Nijmegen method of moral counselling is based on Paul Ricoeur's so-called 'little ethics' (Ricoeur 1992 ch 7-9, pp 169-296; Ricoeur 2000), in which Ricoeur looks for wisdom in real-life situations by exploring different ethical theories as they complement each other. People can avoid the dilemma of having to choose between that which is considered to be good and that which imposes itself as obligatory by interrelating the two and making their choice or decision on the level of practical wisdom. Ricoeur's thinking provides a number of concepts that are used as a listening grid in counselling interviews, which helps to create a structure in the client's moral chaos or confusion. In this paragraph we use his view for analysis of a concrete case from our pastoral practice in the hospital.

Ricoeur opens our eyes to two different ways by which people make moral decisions. One entails asking whether a given decision is 'good'; the other asks whether something is permissible or even mandatory, hence obligatory in the particular situation. The first is more concerned with values and the intention or goal of an act, whereas the second tends to look at the norm on which action is based. The latter tends towards a procedural ethics with due regard to the rules for decision making, whereas the former tends towards substantive evaluation. Ricoeur tries to link the two approaches in a complementary approach, which yields a more comprehensive concept: that of situational or practical wisdom.

Ricoeur distinguishes between three aspects of ethics. When judging whether something is ethically justified, one can ask oneself whether one can justify his action to himself, and to people with whom one has a meaningful relationship (i.e. significant others) and, in addition, to various 'just' institutions (anonymous others, i.e. each). Ricoeur answers these three questions with the aid of teleology, deontology and the ethics of practical wisdom respectively. As an illustration of the described theory we present and comment on the case of Iris. This case has previously been published in a Dutch article (de Groot \& Evers 2007)

Iris is 31 years old. She has been living together (unmarried) with her partner Paul for 4 years. Paul has Huntington disease. It is a hereditary disease, which becomes manifest around the age of 40, but can be diagnosed earlier, even before birth. Paul was diagnosed with Huntington at the age of 27. Paul's mother also had Huntington and died from the disease. In his family his grandmother and aunt also died from Huntington. The father of Paul became an alcoholic because of the resulting problems. Paul has two sisters; one who also knows that she has Huntington, and one who has not taken a test and does not want to know if she has it.

Iris grew up in a city and currently lives in a suburb. Both of her parents are still living. Iris was baptized and raised in the Roman Catholic Church. She did her first communion and confirmation before the age of 12. She rarely attends church, as is currently the case with her parents. She defines herself as a believer. She has a vague image of a personal God and the firm conviction that there is something in the afterlife.

Five years ago she met Paul. After three weeks he told her he has Huntington disease. Total rejection by her family followed. Her parents advised her to break off the fresh relationship. Her brother told her she would be crazy to go through with it. Iris ignored the advice of her family and continued the relationship. Gradually Paul has been accepted by Iris' family. Iris' mother has become especially fond of Paul.

Iris and Paul would like to have children or at least one child. But they absolutely do not want to have a child with Huntington disease. Iris and Paul want prenatal

\footnotetext{
${ }^{1}$ According Ricoeur 'just' refers to the good (Ricoeur 1992 p. 197)
} 
diagnosis with regard to the disorder, but Iris doubts whether she can take the step to abortion if her child has Huntington. She has moral objections against abortion because of her religious background. This was the reason for the psychologist of the Clinical Genetic Centre to refer her to the hospital chaplain.

The problem is greater for Iris, because she has to make her decision almost on her own. Her boyfriend Paul was not raised with any kind of religion and from his view of life there is no problem with abortion. Paul leaves the decision to her. He shares her desire for a child, but not her reservation on abortion. From her family Iris receives indications that abortion to prevent the birth of a handicapped or sick child would be rejected. For that reason Iris does not speak with her family about her situation. She does not tell about the visits of the Clinical Genetic Centre. The topic was difficult enough to discuss in Paul's family. As a result Iris and Paul hardly find an audience in their own circle. They have no real friends with whom they can share their thoughts and feelings about their struggle.

The problem is urgent. If Paul wishes to see his child grow up and if the child is to experience his father in a good condition, they cannot postpone their wish for a child much longer.

The problem cannot be reduced to a clash of convictions. During the first session Iris tells that she is afraid. She is afraid that someone will call her to account for her deed. She wants to speak with the hospital chaplain about the (in) compatibility of abortion with her philosophy of life.

In this case we see all of the elements of Ricoeur's description pass: Iris with her own beliefs, the significant others in her life (Paul, parents, brother, family in law) and several institutions (the church which rejects abortion, the health care system which enables prenatal diagnosis and abortion, the family as a cradle of Teleology morality).

Following Aristotle, Ricoeur defines "ethical intention" as aiming at the "good life" with and for others, in just institutions (Ricoeur 1992 p.172). The judgment that something is good depends on our interpretation of human action, which is based on the interpreters' experiential evidence that their actions comply with the norm of a good life. To this end they use their acquired ability of deliberation (phronèsis). At an ethical level self-interpretation leads to selfesteem.

The good life with and for others occurs when people have solicitude for one another, a kind of benevolent spontaneity. Here Ricoeur relies primarily on Aristotle's concept of friendship (philia) which refers to disinterested friendship as opposed to friendship based on utility or pleasure, because the latter is directed to personal benefit. Genuine friendship implies giving and receiving and is based on reciprocity.

In addition to 'close others' there are 'distant others' - people you don't know and never will know. This variety changes the dimension of friendship into a dimension of justice. Our relationship with anonymous others is conducted via just institutions. Justice implies that we share equally in the well and woe of society. Such equality is not arithmetical but proportional, hence distributive justice: not egalitarianism but distribution pro-rata to capacity.

The focus on the good life with and for others centres on three concepts: (a) in relation to oneself, self-esteem; (b) in relation to significant others, solicitude; and (c) in relation to anonymous others, equality experienced as a sense of justice.

During conversations between Iris and the hospital chaplain diverse elements, which Ricoeur mentions, come up. This happens partly spontaneously and partly because of the questions of the hospital chaplain. She scarcely brings forward the feeling of self-esteem. She only does so when the hospital chaplain explicitly brings it up.

Self esteem

Aiming at a good life for herself it is difficult for Iris to make a choice. She scarcely shows any feeling of self respect or self esteem. She demonstrates a degree of dependency. In the beginning she wished that the physician would 
decide what would be good for her: if necessary an abortion, based on medical grounds, 'because the doctor says it is desirable'. During the second consultation she demonstrates a growing feeling of self esteem.

\section{Solicitude}

In relation to others Iris knows better what is good. She wants to spare her partner further grief and she does not want to involve her parents in her moral struggles. The joint desire of Iris and Paul to have children and the explicit wish that in this child something of Paul will survive is an illustration of their positive appreciation of the current life of Paul and also of their mutual friendship.

As far as Iris views a future child as being another, she expresses mainly solicitude. She wants to prevent her child from having to witness the humiliating death of his father, knowing that he, the child, will come to his end in the same manner. As she literally states: 'I want to save another from a lot of troubles.' In this case Iris' conviction about solicitude is clearly rooted in her observations of experiences concerning significant others. It is not certain that those others have the same experiences as Iris assumes. That is not important for the conversation with the counsellor. The counsellor explores the convictions of Iris.

Sense of justice $\rightarrow$ equality

Her sense of justice is disturbed as she expects of life a reasonable balance between joy and grief, happiness and suffering. She emotionally resists an institution like the church that with an absolute prohibition of abortion imposes a Deontology kind of suffering that threatens to surpass her capacity to bear it.

Ricoeur covers the same ground with reference to Kant, using his ethics - or rather, morality ${ }^{2}-$ as a sieve with which to test Aristotelian ethics. A hallmark of the Kantian concept of morality is the rule of universalization.

A good life for oneself depends on good will. For Kant this pursuit takes the form of a selfimposed obligation based on the categorical imperative: "Act only on that maxim through which you can at the same time will that it should become a universal law." To Kant, good will (i.e. good without qualification) and obligation are interchangeable. Ultimately those who freely choose to will the good are autonomous; autonomy is obedience to a self-imposed categorical imperative. Furthermore, for Kant a good life with and for others occurs when others are treated respectfully. The norm is based on both the Golden Rule as a negative formula ("Do not do unto your neighbour what you would hate him to do to you") as well as a positive formula ("Treat others as you would like them to treat you"). The norm of respect entails seeing others not merely as means, but, at the same time, always as ends in themselves.

Applied to institutions, Kant's rule of justice is formal and procedural. It is based on the fiction of a social contract, in terms of which autonomous human beings relinquish their primordial freedom in order to regain freedom in the form of civil liberties as citizens of a republic. Institutionally, autonomy continues to exist. In the $20^{\text {th }}$ century these freedoms and autonomy were declared universal human rights.

Kant's umbrella concept of universalization is subdivided into three key concepts: (a) in relation to oneself, that of autonomy; (b) in relation to significant others, that of respect; and (c) in relation to anonymous others, the formal rule of justice, laid down in human rights.

Iris lives with strong norms, but she derives her norms primarily from others and from institutions. What about a rule to which she might intrinsically feel obliged? Only after further questioning does she disclose norms for herself, which she also expects others to live by.

\section{Autonomy}

At the beginning of the conversation there is practically no expression of autonomy by Iris. The prescription 'Thou shalt not kill' - which can be considered as a maxim or basic rule - plays an important role. She can hardly defend

\footnotetext{
${ }^{2}$ In Ricoeur's thinking the term 'ethics' is reserved for the Aristotelian teleological line and 'morality' for the Kantian deontological line.
} 
abortion to herself, not to speak of defending it with a view to a future child. She uses the word 'murder'.

Respect

She respects her boyfriend, her parents as well as the future child. She threatens to get stuck in a situation in which her boyfriend requests abortion, her parents reject a daughter who would undergo abortion and the child could end up in misery. A transition to wisdom suggests itself, because she cannot please all 'parties' with her decision.

Human rights $\rightarrow$ justice

Iris derives the right to life for her child from human rights. She is not allowed to dispose of his live. The church underlines the right to live with the prohibition of abortion, even in an extreme situation. Iris wants to respect this right to life, but it is in conflict with her perception of a right to avoid suffering.

Practical wisdom

Ricoeur continues his argumentation using the illustration of the Greek tragedy, Antigone. His argument shows that both Aristotelian ethics and Kantian morality may be inadequate in real-life situations. The word 'tragedy' is instructive when it comes to Ricoeur's notions on ethics, since they depict a tragic wisdom that can guide us in diverse conflicts. Conflicts arise from people's characters as well as moral principles and the complexity and opacity of life. Ethics and morality are always applied in concrete situations that can sometimes be truly tragic. In such cases the only solutions are to resort to wisdom or common sense.

Judgment in a situation is always invoked when people aim at the good life with and for others in just institutions. Whereas self-esteem (based on phronèsis) and autonomy had previously been the ethical and moral yardstick for a good life for oneself, Ricoeur integrates them: phronèsis becomes a critical phronèsis, in which self-esteem is viewed critically in terms of the norm of autonomy and the concomitant requirement of universalization. A person has to balance acting-in and undergoing a situation, between activity and passivity before coming to a resolute choice.

A good life with and for significant others requires not only solicitude (Aristotle) and respect (Kant) but also availability or disposability ('disponibilité' - Marcel). This availability is expressed in others' expectation that "I can be relied upon to do what I commit myself to do". Ricoeur points out that practical wisdom sometimes requires us to ride roughshod over the Golden Rule out of solicitude for the other - in other words, respect for that person sometimes prevails over respect for the rule. Practical wisdom calls for critical solicitude concretised in commitment as a combination of friendship and compassion.

What justice and goodness entail in an institutional environment can never be defined in absolute terms. Something this fuzziness is good and just in a political sense but may not be so from an economic, social or cultural angle. It always entails debate, the outcome of which cannot be determined scientifically or dogmatically. In advanced democracies common sense and careful deliberation (euboulia) - when effective - culminate in a majority vote after public debate. But even democratically enacted laws, however good and just their intention, do not always have the final say in real-life situations. Again Ricoeur resorts to Aristotle, who raises the issue of equity. Equity remedies justice "where the legislator fails us and has erred by over simplicity" (Ricoeur 1992 p. 262). In real-life situations the universality of law can result in inequity, in which case the law has to be corrected. Further public debate is needed to give equity a chance if application of the rule of justice (Kant) or sense of justice (Aristotle) violates it.

Hence, Ricoeur proposes an ethics of practical wisdom - others speak of situational ethics which he defines more specifically as a dialectical ethics, expressed in reflective equilibrium between the ethics of argumentation and considered convictions (Ricoeur 1992 p. 289). His ethics is summed up by the concept of practical wisdom as applied in real-life situations, where it manifests itself (a) in relation to oneself in the form of critical phronèsis, weighing activity against passivity, which leads to resoluteness; (b) in relation to significant others as critical solicitude, weighing friendship against compassion, concretised in commitment; and (c) in relation to anonymous others (at an institutional level) as equity, weighing rules against a sense of justice. 
After three sessions Iris is almost ready to make a decision. She is carefully considering her options, but she is growing at the same time in resoluteness.

Activity / passivity $\rightarrow$ resoluteness

Iris presents herself as the one who has to make a decision actively, but also as a victim of the situation. She is a direct object in as much as she suffers from the disease of her partner. She resists against more suffering and endeavours to save her child from misery. In her deliberation the awareness grows that she too is a victim. That gives her a sense of strength in confronting circumstances that she cannot all control.

Friendship / compassion $\rightarrow$ commitment

In her deliberations Iris demonstrates the conflict of values between solicitude for her partner and the future baby and the compassion which she will have with her genetically encumbered child. Besides that she respects her partner and child. For her partner friendship seems to prevail, articulated in loyalty for better and worse. For her child compassion seems to be the most the first priority, articulated in the will to prevent misery for an affected foetus.

Sense or rule of justice $\rightarrow$ equity

The conflict in Iris is rooted in her tie to the church that has morally educated her. Even though she is not active in the church and ignores a number of guidelines of the institution, in this boundary situation the influence of the church is stronger than Iris would like. Yet after two sessions she is inclined to test the prescriptions of the church on the standards of goodness and justice. In careful deliberation she questions (in religious language) whether it would be fair for her to have to accept even more suffering. With due respect for the rule she will in last instance appeal (not versus the church but versus God) to circumstances beyond her control.

Summary in a 'listening grid'

From Ricoeur's 'little ethics' we derive the following scheme that serves as a 'listening grid' in our method.

\begin{tabular}{|l|l|l|l|}
\hline \multicolumn{4}{|c|}{ Box 1: Ricoeur's key concepts in regard to moral counselling } \\
\hline & $\begin{array}{l}\text { a good life for oneself } \\
\text { (self) }\end{array}$ & $\begin{array}{l}\text { with and for others } \\
\text { (other) }\end{array}$ & $\begin{array}{l}\text { in just institutions } \\
\text { (each) }\end{array}$ \\
\hline value & self-esteem & solicitude & equality \\
\hline norm & autonomy & respect & justice \\
\hline conviction & resoluteness & commitment & equity \\
\hline
\end{tabular}

The case shows something of the dialectic between argumentation and conviction. The result is a decision of moral judgment with an inclination towards termination of pregnancy should the foetus be tested as having Huntington.

The ethical theory of Ricoeur delivers a practical framework to account for all deliberations and arguments made in moral counselling. In the secondary analysis, it is possible to observe that some facets which might be important for a moral decision remain unexposed or underexposed. For a hospital chaplain who seeks to work systematically in moral counselling the theory and the proposed grid with keywords can be helpful in calling the attention of the client to all the facets of moral deliberation.

Rogers's non directive counselling method applied

Many caregivers -psychologists, psychiatrists, social workers and hospital chaplainsare familiar with Carl Rogers's counselling method. Many people with moral problems are counselled according to his method. It has been our experience that following non-directive counselling becomes a directed approach by implementing the aforementioned grid of Ricoeur provides better results than an exclusive non-directive approach. We start here by summarizing the ideas of Rogers. 


\section{Counselling following Rogers}

Rogers was innovative in centring the helping relationship on the client's person rather than on the problem. That shifts the accent from the counsellor's extraneous input to the person's own drive for growth, health and adaptation. The emphasis is placed on feelings rather than knowledge and intellect, on present experience rather than the past. In short, the helping relationship is in itself a growth experience (Rogers 1942 p. 28-30). Rogers links this with an optimistic view of human nature, which assumes that people have a natural potentiality for learning and that the counsellor can help them learn by stimulating them to be independent, creative and self-reliant. In the process the client must realise that self-criticism and self-evaluation are more important than evaluation by others (including the counsellor) (Rogers 1969 p. 157-163). In a sense the client (re)gains control of his life. This type of helping dialogue is known as non-directive or client-centred counselling (Rogers 1951 p. 45).

The counsellor offers clients a relationship that the latter can use for their personal growth. The counsellor's basic attitude in forming the relationship has three elements, which Rogers (1966 p. 184) enumerates: "These three conditions are the therapist's congruence or genuineness; unconditional positive regard, a complete acceptance; and sensitively accurate empathic understanding."

Rogers and Ricoeur

To explore moral problems one needs more than non-directive counselling. To come at the point of practical wisdom one needs some directiveness. The guide for the directiveness is the grid of Ricoeur. It aids the counsellor in enabling a client to find an outcome.

We consciously avoid the word 'solution', because some problems cannot be solved even though they require decisions. This feature is especially the case in tragic situations when each solution entails some loss, as in the example of abortion. Nevertheless, decisions must be made. The counsellor assists in decision making by interrelating the client's values and norms and, via the sieve of universalization, leading them toward a decision that may become defined as a firm conviction: 'Here I stand, I cannot do otherwise.'

The counsellor's primary task is to listen to the norms and values that the client invokes in relation to the question or problem being faced. According to the Rogerian method, the counsellor tries to enable the client to engage in self-dialogue and thus probe deeper, leading to exploration of the client's attitudes. Another way in which counsellors do this is by searching the client's life story for the source of certain values (Hermans and HermansJansen 1995; Hermans and Hermans-Jansen 2004) and norms and the resultant ideas and beliefs. The counsellor focuses primarily on statements by the client that contain a moral or ethical dimension. The counsellor then proceeds with the client to convert these into 'Istatements'. The statements clarify to the client what values and ideals the client strives for, what is regarded as mandatory or forbidden to him or her, and what convictions each has acquired from previous experience. 'I-statements' at the level of values and ideals often start with 'I want to......', and at the level of norms with 'I must....' or 'I may......'. At the level of convictions the client frequently refers to an attitude acquired through bitter experience: 'I'll never do that (again)' or 'I shall always...' The conviction is applied to the real-life situation and leads to a kind of resoluteness. Statements are usually at the level of values and norms, most clients putting the accent on either values or norms. Next, the statements are classified under the client's direction and with the aid of the listening grid. Once the client has talked extensively, counsellor and client together review the listening grid and together decide whether there are 'blank spots'. Sometimes clients locate their values and norms mainly outside themselves and/or in institutions; sometimes they find these mainly in themselves and disregard the values and norms in society or those that pertain to the circle of their significant others. The counsellor invites the client to fill in the 'blank spots', for often clients do have stories about these. They do not chance on them spontaneously. In this respect

\footnotetext{
${ }^{3}$ The term 'blank spot' and the procedure we derive from the Johari window (see Luft \& Ingham 1955).
} 
the counsellor's questions are guided by Ricoeur, while the answers are probed mainly by means of Rogers's counselling method.

Practical experience: first correction

As noted previously, Ricoeur's scheme was initially used primarily to analyse conversations after an event and, on the basis of that analysis, continue the discussion in a subsequent session. Later on Ricoeur's scheme was used to help a client come to grips with the moral problem identified in the first contact. Many such identified problems concerned decisions about life and death. Clients were counselled on whether they had the right to ask for euthanasia. Patients asked themselves whether they wanted to continue treatment. Women discussed the question of abortion following the outcome of prenatal diagnostics or hereditary diseases in the family. The method was also used for problems in pastoral practice. Here, clients were frequently concerned child rearing (see box 2) or relational issues of a highly moral quality. Both in the hospital and in pastoral practice, people approached the counsellor asking whether a particular choice or decision was good and/or correct, both retrospectively and prospectively. The counsellor tried to translate these questions into the question, "What would be wise in this situation?" and then look for an answer by interrelating goodness and obligation. The counsellor's pastoral background provided the advantage of familiarity with various hermeneutic and dialectic methods.

A first correction arose in situations that the counsellor wanted clients to arrive at a swift decision or choice or in situations in which the counsellor tried explicitly to get the client to reach a conclusion, goals that were not always achievable. Often, the outlines of decisions or choices would emerge. When a client would announce readiness to make a decision, the counsellor would respond by not going much further in subsequent sessions. Often the counsellor merely clarified the client's values and norms and provided a (sometimes written) review of various values and norms as they existed in the client's mind and feelings. Then the discussion could be terminated, with the unasked advice to sleep on it once more and/or a suggestion to discuss it again with some significant other. The latter would be easy, since the client had gained greater insight into her own norms and values and could raise them confidently in a discussion.

Another correction based on practice resulted from many clients' insistence on dealing with the non-rational dimension of their deliberations. The counsellor wanted to pay due attention to such questions and was able to draw on the ideas of Nussbaum and Brennan, which require a new paragraph.

Nussbaum and Brennan in combination with Rogers and Ricoeur Nussbaum

In developing our counselling method we became obliged to consider how people make decisions and choices and, thus, the relation between reason and emotion in the discernment process. In our experience, people facing a moral dilemma or ethical decision often have already (or almost) made a decision intuitively, although logically or intellectually they have not (yet) reached that point. Martha Nussbaum points to a way by which the condition of such certainty and confidence can emerge from which nothing can dislodge us; it is not reducible to logical arguments. In Love's Knowledge (1990) Nussbaum maintains that we sometimes know things with certainty without sound supportive arguments. In the moral domain in particular, we have certain convictions that are decisive for our choices or decisions, even though we are unable to justify these rationally. These are known as cataleptic impressions that compel assent by their intrinsic nature. In this case, the compelling impressions are emotional and are so powerful that the superficial impact of the intellect does not stand the slightest chance against them. We come close to such an impression when we know for sure that we like somebody without being able to offer a sound reason why.

In Upheavals of Thought: the intelligence of emotions (2001) Nussbaum works this out in greater detail. Following Proust, who inspired the title of Nussbaum's book, she argues that 
emotions are appraisals or value judgments ${ }^{4}$. She sees them as loci of ethics or morality. They have a cognitive, evaluative aspect: emotions contain a notion of human well-being and of the principal problem situations in human life.

Brennan

Brennan, too, traces ethics to emotional experience. We acknowledge his viewpoint and share his experience that there are people who feel indignant about the (moral) dilemma with which they are confronted. The indignation stems from a kind of contrast experience such as people may have when they say or feel that a particular situation is simply not just. It happens even to children - they cry, 'It isn't fair!' even to their educators, who learn from it that emotion is one of the loci of ethics or morality. This plaint takes us into the territory of justice and injustice (Ricoeur 1992 p. 198). Pronouncing something 'unfair' implies a certain conception of what is 'fair'. Brennan calls the indignation prompted by such an experience "moral perplexity" (Brennan 1977 p. 32-35); people are perplexed by the fact that they consider something right or wrong. They experience a particular action, omission or situation as morally problematic. If they had no moral standards, they would have no moral problems. Apart from knowledge about the issue, moral perplexity presupposes some measure of moral commitment and some knowledge of moral values, otherwise how could one be perplexed? Facts are always judged on the basis of a moral preconception (Brennan 1977 p. 93). Moral problems do not arise from brute facts but from an interpretation of these facts according to an accepted moral standard. One difficulty emerges if we assume that moral problems arise only in relation to previously accepted standards: we have to allow for the acceptance or modification of standards. The necessity for such allowance is the basis for Brennan's concept of the "open-texture of moral concepts". In his view, moral concepts and moral judgments are continually evolving. They acquire new moral concepts the way they learn a language: new words are added to their existing vocabulary, giving existing words a new tone and tinge. Individual schemes of moral concepts are not a rigid framework but remain an open texture (Brennan 1977 p. 94). Kohlberg (Kohlberg and Puka 1994) underscores the possibility of the evolution of moral thought. There is always a possibility of growth in thinking about good and evil, permissible and impermissible, right and wrong.

Brennan sees paradigmatic comparisons as a way of overcoming moral perplexity. Thus, a woman may consider asking for an abortion because of a hereditary or congenital disorder in her child (e.g. spina bifida). On the basis of a paradigmatic comparison with other disorders, she may then take a decision in her actual situation (e.g. by asking herself, "if the child were blind, would I also consider abortion?").

Hence, instead of looking for hard criteria of correct classification, Brennan uses implicit criteria deriving from what is known as a paradigmatic case. To determine whether something is morally good, right or permissible, he looks for a comparable case that can serve as a paradigm (example, model) for the present case. Brennan is conscious of abuse of casuistry (see Jonsen and Toulmin 1988), but he sees no other way than to work with paradigmatic cases. Passing a moral judgment is simply declaring that a given moral hypothesis is true or false with a given degree of probability. This judgment has to be based on "moral inquiry".

We are familiar with the hypothetic deductive model of scientific research. A theory emerges inductively, whereupon it is formulated as a hypothesis and tested deductively. Facts and arguments lead to a particular conclusion. In moral inquiry, the argumentation assumes a different form. Deductive reasoning is a dead-end street. One cannot always proceed from a universal law that is then applied to a specific situation. Neither can one persist in doing the same thing in all similar situations. In this respect Brennan anticipates Ricoeur's concept of situational wisdom by acknowledging the impossibility of always proceeding on the basis of universal principles. Thus, like Ricoeur, he introduces a correction of Kant's work.

\footnotetext{
${ }^{4}$ The idea of emotion as a "significant driving force in moral judgment" is also underscored by Greene and Haidt (2002 p. 522). The latter elaborates it into a "social intuitionist model" (Haidt 2001).
} 
Nussbaum and Brennan in conjunction with Ricoeur and Rogers

Nussbaum and Brennan, in particular, draw our attention to that which precedes the weighing of arguments. They make us realise that certain ideas, attitudes, or values precede the diverse norms and rules imposed on us either by ourselves or by others and social institutions. These ideas, attitudes, or values withstand rules, but they remain open to readjustment and correction. This is what Ricoeur calls a sieve that we characterise as the sieve of universalization. The client's moral self-reflection - a kind of inner dialogue spoken aloud - is facilitated by the moral counsellor, who merely organises it and calls attention to blank spots (Luft and Ingham 1955). In so doing the counsellor probes the person's depths mainly by reflecting on what the client is saying at a deeper (attitudinal) level and encourages the client to take it further. The most commonly used interventions, using the categorisation system of Stiles (1992), are called reflection and acknowledgment.

Development of a course in moral counselling

In discussions with colleagues about these operational methods, we were challenged to account for the efficacy and utility of this approach. Thus, our next task was to convey to our colleagues what had hitherto been used only in our own practice- in this case, also as hospital chaplains in a university hospital. We designed a course in moral counselling. For strategic reasons, the moral counselling course was offered in conjunction with a (short) course in the Nijmegen method of moral case deliberation (Steinkamp 2009) since he target group was comprised of those who not only must be able to help clients with moral problems, but who can also participate in and even guide moral case deliberation between caregivers. The components of the course on the Nijmegen method of moral counselling included:

Preparation of the course

To enable participants to prepare for the course we compiled a syllabus comprising the following:

- a brief description of the Nijmegen method of moral counselling. The description has also been published as an article in the journal of the professional group of hospital chaplains (de Groot 2006);

- an article by the colleague who was involved in structuring and conducting the course (Evers 2006);

- an article on open interviews by Ilja Maso from the Werkboek Practicum Interview-en observatie training (Workbook Practicum Interview and Observation Training);

- a manual on the method of moral counselling, edited by the counsellor, i.e. the first author of this article. Excerpts from this manual have been incorporated into this article.

In the invitation to the course participants were given a preparatory assignment to record two cases:

- a moral dilemma from the participant's own life;

- a case in which the participant dealt professionally with a client who had a moral Trial run problem that required counselling.

In preparation for the course, trial runs were conducted with teams of five chaplains at two academic hospitals. The first exercise was role play to learn counselling in depth, the instruction being to explore moral attitudes in particular. After a theoretical clarification of both the counselling skills and the aforementioned listening grid, participants learned through role play to apply the model. One role play was of such a calibre that it was decided to use it as an instructional video in the eventual course (see box 2). This case was also described in a publication of the two course leaders (de Groot \& Evers 2007). In this case the dilemma of choosing between safety or adapting was overcome by the concept of resiliency.

Box 2 - instructional case

A father comes to a pastor with a question, which he circumscribes as a moral problem. He has to make a decision based on norms and values, which are important to him. The pastor suggests examining the problem according to the Nijmegen method of moral 
counselling. He explains the method. After that the problem is specified: "I have to decide about my daughter of 5 years, whether she has to wear a biking helmet since she is soon going to be able to bike independently."'What is your first intuition?" asks the counsellor. "I want her to wear one for her safety. But I don't want her to be ridiculed". The father asks out loud: "What should I decide? I want to protect her in case she falls, but I also want to protect from becoming an outsider in her peer group."

The pastor invites the father to tell more. The father tells about experiences in which his daughter was teased and he stood up for her. At further invitation of the pastor the father tells how he had seen, that his mother stood up for her children and how he self stood up for his brother.

On the question what is wisdom in this situation the father admits that he always emphasizes safety first. He is a first-aid practitioner and an emergency response officer, but that one can be too concerned. The pastor confronts the father with the fact that he always is full of attention and solicitude for others. He asks the father what he feels himself. That brings the father in his puberty, where he developed a kind of resistance to the norm of his parents to 'mind about what other people think'. In important situations he has gone his own way in life, independent of 'what other people think'. "I want my daughter to learn that, too." "What does that mean in this situation?" asks the pastor. "I think I have to help my daughter to persevere in such a situation. When people laugh because she wears a helmet, that tells me more about those people than about my daughter. But I think, that she is allowed to say to me: Dad, I can bike so well now that I don't need the helmet any longer.' About his decision the father says: "I think I am almost clear. I can decide what I think is important for my child, regardless of what others think about that." And: "Do you keep your child from an outsider by forcing her to conform to others. I will talk with my wife about it. I think we have to support our daughter and make clear that we do it in our own way. It is a challenge to help her become resilient in that respect."

\section{Three-day course}

The moral counselling course was comprised of six sessions. Five of these are applied to practical exercises, mostly role play recorded on video and then discussed with the help of observation assignments based on certain analytical schemes.

The introductory session, itself, served as a practical exercise. Initially, the free interview method was used to get to know one another.

The second session focused on how people make decisions in situations where they are confronted with moral dilemmas, decisions or choices. Each participant presented a personal moral problem who then explained how it was managed or - if the problem had not yet been resolved - what processes were at work in the participant's heart and mind. One observation that emerged was that some participants were strongly influenced by certain values or principles, whereas others put the accent on norms and rules. This finding provided an opportunity to discuss Ricoeur's 'little ethics', focusing on values and norms as well and how to bring them in relation to each other. Attention was given to the variety of perspectives one can adopt: one's own, that of a significant other, and that of anonymous others.

The third session was an exercise based on box 1: two exercises in which participants were asked to submit a personal problem to a counsellor. The counsellor had to classify, as far as possible, everything raised by the client according to box 1 . The observers did the same and at the end they exchanged their results.

The fourth session was aimed at enabling participants to trace blank spots. The Johari window (Luft and Ingham 1955) was presented and two participants were asked to discover a colleague's blanks spots in a real-life case, using the free interview method.

The fifth session was another role play exercise, building on the experience gained from the earlier role play, but this time the counsellor and observers paid special attention to ambivalences and contradictions between different statements. This session was preceded 
by a video lesson with the role play from the trial course. From the role play it emerged that certain deeply rooted experiences were ultimately decisive in a person's evaluation of a moral problem, a good example of a cataleptic impression.

The sixth session took the form of a teaching-learning discussion and culminated in the final exercise: a role play dealing with the termination of a moral counselling interview.

Evaluation and follow-up

Conducting the first course strengthened our conviction that the Nijmegen method of moral counselling is superior to methods focusing on one person only. Insights and skills gained by an individual proved to be transferable to other professionals, confirming the efficacy of the method. Participants in the first course suggested that there should be a follow-up course to explore the skills in greater depth. The course leaders suggested that the interim period be used for practice and that the follow-up course should include an interview protocol that can be used for analysis. The course leaders are also pastoral supervisors for Clinical Pastoral Education. By virtue of that they were familiar with and proficient in a method of protocol analysis developed to analyse pastoral interviews (Van der Ven 1994). For analysis they used qualitative and quantitative methods and also scientific software such as Atlas.ti ${ }^{\circledR}$. The follow-up course was duly conducted six months after the first one.

The first (foundational) course led to a joint publication by the two course leaders (de Groot \& Evers 2007), which served as a basis for all subsequent courses. Since then eight foundational courses have been offered, two of them as an in-company-training. Altogether 65 people participated. Two times there was a follow-up course. Participants were hospital chaplains and psychotherapists, nurses, physicians, social workers and teachers in ethics. The course is now accredited and listed as a recognised course in the professional register of spiritual counsellors (VGVZ).

Conclusion: relation between spiritual care and ethics

The Nijmegen method of moral counselling can contribute greatly to quality of care. In the past, patients facing a difficult choice were supported mainly by providing a maximum of intelligible information as a result of the stipulation regarding informed consent. The Nijmegen method of moral counselling seeks to supplement this intake information. However, the focus is not on the (medical) information that must be provided to a patient. Rather, it is cantered on the person's own system of norms and values. By investigating and clarifying these dimensions systematically, the counsellor enables patients to become more aware of arguments and intuitions on which to base an evaluation of the information provided. Guiding this process requires a different competence than that of providing intelligible information. In the ranks of health care professionals, hospital chaplains are the most obvious candidates for the role of moral counsellor. They are professionally trained in conducting helping interviews; they are familiar with the importance of hermeneutics and narratives in conversation; they can act as 'disinterested listeners' and trusted figures; they are familiar with the care domain; and they have an innate affinity to ethics. In the professional standard of the Dutch Association of Spiritual Counsellors in Care Institutions (VGVZ-cahiers 2 2002), ethical counselling at the micro-level is listed as one of their tasks. The Nijmegen method of moral counselling is a tool designed for this purpose.

The component of moral counselling enhances the pastoral counsellor's roles by providing another instrument for the ethical debate in the hospital. Moral counselling can be as necessary for the patient as is moral deliberation for the physician (de Groot 2008). Moral deliberation consists in dialogue, headed by a clinical ethicist, between all caregivers involved in a particular case (Steinkamp 2009). The tools of moral counselling can embellish the hospital chaplain's position in the institution. If hospital chaplains also explicitly present themselves as moral counsellors, it is likely they will no longer be called in only when spiritual or worldview-related questions are at issue, but also when there are moral problems. In such cases, hospital chaplains take on a 'position' alongside the patient, in contrast to the clinical ethicist, who is primarily a moderator in caregivers' ethical discussion of the case. As mentioned already, the Nijmegen method of moral counselling should be seen as complementing the Nijmegen method of moral case deliberation. Hospital chaplains who are also the institutions' ethicists now have an additional capacity, and hospital chaplains who 
serve mostly in a pastoral or spiritual role now have additional tools complementing those of the clinical ethicist.

Acknowledgments

The authors would like to thank all the colleagues who gave feedback on courses and publications about moral counselling. Special thanks to Hans Evers, who gave an important contribution to the Nijmegen method of moral counselling and the development of the course as well.

This paper is the result of work performed as part of the educational programme European Master's in Bioethics.

\section{References}

Brennan JM (1977) The open-texture of moral concepts. Barnes \& Noble, New York.

Cattorini, P (2001) Clinical Bioethics. Identity, Role, Aims. Medicina nei secoli Arte e Scienza 13:187-197

de Groot, J (2006) Geestelijke verzorging en morele besluitvorming. Introductie van de Nijmeegse

methode voor morele counseling. Tijdschrift voor Geestelijke Verzorging 9:26-37

de Groot, J, Evers, H (2007) Morele counseling. Presentatie van de Nijmeegse methode.

Praktische Theologie 34:314-332

de Groot, J (2008) Morele counseling voor de patiënt als pendant voor moreel beraad.

Tijdschrift voor Gezondheidszorg en ethiek 18:107-111

Egan G (1997) Skilled helper: a problem-management approach to helping. Brooks/Cole, Pacific

Grove, Calif. [etc.] :

Evers, $\mathrm{H}$ (2006) Als voortbestaan niet meer vanzelfsprekend is. Pleidooi voor systematische ondersteuning en begeleiding van de existentiële ontwikkeling bij patiënten en naaststaanden 61

tijdens een langdurig intensive care verblijf. Tijdschrift voor Geestelijke Verzorging 9:51-

Greene, J, Haidt, J (2002) How (and where) does moral judgment work? Trends in Cognitive Sciences

$6: 517-523$

Haidt, J (2001) The Emotional Dog and Its rational Tail: A Social Intuitionist Approach to Moral

Judgment. Psychological Review 108:814-834

Hermans HJM, Hermans-Jansen E (1995) Self-Narratives. The Construction of Meaning in

Psychotherapy. Guilford Press, New York - London

Hermans HJM, Hermans-Jansen E (2004) Het verdeelde gemoed. Over de grondmotieven in ons

dagelijks leven. Nelissen, Soest

Jonsen AR, Toulmin SE (1988) The Abuse Of Casuistry. A History of Moral Reasoning. University of

California Press, Berkely - Los Angeles - London

Kohlberg L, Puka B (1994) Kohlberg's original study of moral development. Garland, New York

Luft J, Ingham H (1955) The Johari window, a graphic model of interpersonal awareness.

Proceedings

of the western training laboratory in group development. UCLA, Los Angeles

Nelson WL, Han PKJ, Fagerlin A, Stefanek M, Ubel PA. (2007) Rethinking the Objectives of

Decision Aids: A Call for Conceptual Clarity. Medical Decision Making 27:609-618.

Nussbaum M (1990) Love's knowledge. Essays on philosophy and literature. Oxford University Press,

New York 
Nussbaum M (2001) Upheavals of thougt. The Intelligence of Emotions. Cambridge University Press,

Cambridge

Ricoeur P (1992) Oneself as Another. University of Chicago Press, Chicago

Ricoeur, P. (2000). Prudential judgment, deontological judgment and reflective judgment in medical

ethics. In: Kemp, P.; Rendtorff, J.D.; en Johansen, N.M. (eds). 2000. Bioethics and biolaw. Vol I

Judgment of life. Copenhagen.

Rogers CR (1942) Counseling and Psychotherapy. Newer concepts in practice. Houghton Mifflin,

\section{Boston}

Rogers CR (1951) Client-Centered Therapy. Its current practice, implications and theory. Houghton

Mifflin Company, Boston

Rogers CR (1966) Client-centered Therapy. In: Arieti S (ed) American Handbook of Psychiatry. Basic

Books, New York / London, pp 183-200

Rogers CR (1969) Freedom to learn. Charles E.Merrill, Columbus, Ohio

Steinkamp NL (2009) Ethical deliberation in healthcare organizations. Studie on structures and

methods. Nijmegen (dissertation)

Stiles WB (1992) Describing Talk. A Taxonomy of Verbal Response Modes. Sage, Newbury Park,

California

van der Ven JA (1998) Education for reflective ministry. Peeters Press Louvain / Eerdmans Grand

Rapids Mich

van der Ven JA (1998) Formation of the moral self. Eerdmans, Grand Rapids, Mich

VGVZ-cahiers 2 (2002) Beroepsstandaard voor de Geestelijk Verzorger in Zorginstellingen.

Amersfoort 


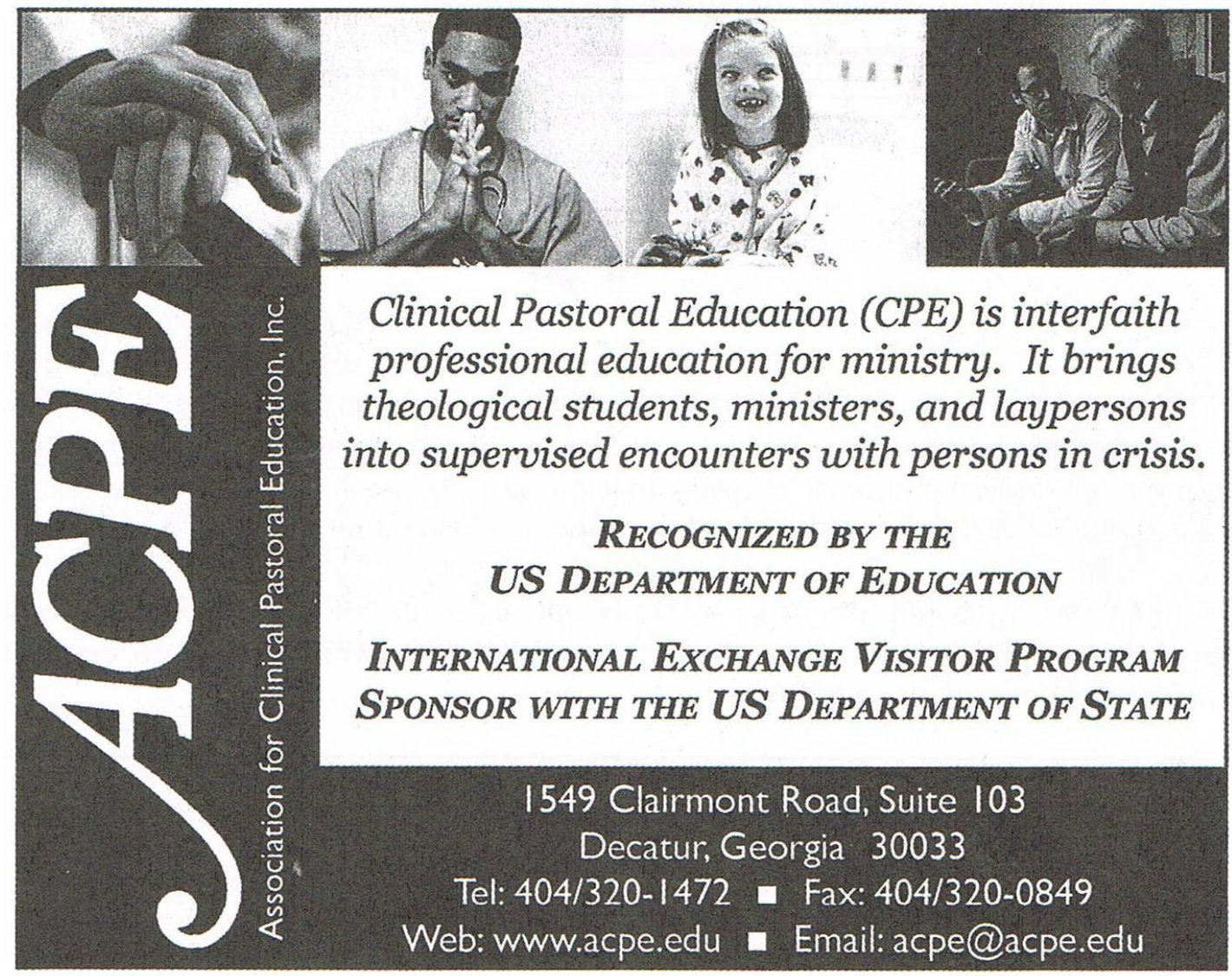

